\title{
ORDENAÇÃo MORAL DE MUNDO E JUSTIFICAÇÃO DA EXISTÊNCIA NA METAFÍSICA DE SCHOPENHAUER ${ }^{1}$
}

\author{
Wander Andrade de Paula ${ }^{2}$
}

\begin{abstract}
Resumo: Arthur Schopenhauer ficou conhecido como o pensador do "pessimismo filosófico". Tratase de uma doutrina que, em linhas gerais, apresenta uma determinada interpretaçáo acerca do valor do mundo, mas que, em seu sentido ainda mais básico, questiona a possibilidade de atribuição de valor ao todo da existência: há "justificaçâo" (Rechtfertigung) para a existência? A partir da resposta a essa pergunta, o filósofo alemão desenvolve sua "metafísica da vontade" e, como seu desdobramento, sua teoria da "redenção" (Erlösung), ou soteriologia. Entretanto, o "filósofo do pessimismo" também afirma, em sua obra, que há uma "ordenação moral de mundo" (moralische Weltordnung) e um "significado moral da existência" (moralische Bedeutung des Daseyns), o que parece ir na direção oposta ao "pessimismo". O presente artigo analisa o significado das noçóes de ordenaçáo moral de mundo e justificação da existência no pensamento de Schopenhauer, a fim de demonstrar em que medida significado moral da existência e pessimismo filosófico se relacionam no pensamento do autor.
\end{abstract}

Palavras-Chave: Arthur Schopenhauer. Metafísica. Pessimismo Filosófico. Ordenação moral de mundo. Justificação da existência.

Estabelecer um vínculo entre a força que produz o fenômeno do mundo, e em consequência determina a sua natureza, e a moralidade do etos, e assim demonstrar uma ordenação moral de mundo como a base da física - este vem sendo o problema da filosofia desde Sócrates.

(SCHOPENHAUER, O mundo como vontade e representação, v. II, c. 47).

\footnotetext{
${ }^{1}$ Algumas das ideias centrais do presente texto foram desenvolvidas ainda como parte do meu PósDoutorado na Universidade Estadual de Campinas (UNICAMP), com financiamento da FAPESP (processo no 2013/09544-3, Fundação de Amparo à Pesquisa do Estado de São Paulo [FAPESP]).

${ }^{2}$ Professor Adjunto de Departamento de Filosofia e do Programa de Pós-Graduação em Filosofia da Universidade Federal do Espírito Santo (UFES), Vitória, ES - Brasil. (D) https://orcid.org/00000002-7552-9844
}

http://dx.doi.org/10.1590/0101-3173.2020.v43n1.15.p255 


\section{INTRODUÇÁO}

O "pessimismo filosófico" parece ser, não sem boas razões, a principal alcunha pela qual o pensamento de Schopenhauer é tradicionalmente identificado. Nem tanto por considerar este o "pior dos mundos possíveis", e bem mais por afirmar que o "não ser é preferível ao ser", isto é, que não há justificação (Rechtfertigung) para a existência (cf. esp. GERHARDT, 1989; e DAHLKVIST, 2007, p. 14), o pessimismo schopenhaueriano se torna uma referência de como parte considerável do século XIX alemão concebia a própria tarefa filosófica: como uma tentativa de dar resposta ao "problema" da "vida", o que pressupóe, antes de qualquer coisa, que a própria vida é tornada um problema pela filosofia (cf., p. ex., PFLUG, 1989, col. 139-140, e SCHNÄDELBACH, 1984, p. 139-145).

Há, contudo, no interior da própria filosofia de Schopenhauer, uma questão que vem demandando cada vez mais atenção dos intérpretes: a das razôes de sua concepção de metafísica "imanente" possuir uma "significação moral" ou, dito de outro modo, que razóes levam o autor a defender uma "ordenação moral de mundo", na sua interpretação "pessimista" da existência (cf. esp. KOSSLER, 2014). O objetivo do presente texto é oferecer uma resposta a esse problema: qual a relação entre o "pessimismo filosófico", ou seja, a interpretação segundo a qual não há uma justificação para a existência, e a "ordenação moral de mundo", isto é, a concepção de que a metafísica possui originariamente uma significação moral? Para tanto, far-se-á necessária (1 e 2) uma breve incursão no conceito de metafísica de Schopenhauer, tanto do ponto de vista de sua origem quanto do significado de sua "imanência", passando por (3) uma discussão de alguns aspectos centrais - e caudatários da discussão anterior - da doutrina da virtude e soteriologia schopenhauerianas; com o que, então, estaremos aptos a compreender (4) a relação entre metafísica e ordenação moral de mundo, e (5) responder se a tal ordenação moral de mundo corresponde uma justificação da existência no pensamento do autor.

\section{O CARÁTER ENIGMÁTIDO DA EXISTÊNCIA: A ORIGEM DA METAFISICA}

Schopenhauer afirma, no capítulo "Sobre a necessidade metafísica do homem", do segundo volume de sua obra magna, O mundo como vontade e representação, que, ao contrário dos outros animais - nos quais vontade $\mathrm{e}$ intelecto não são separados o bastante -, o homem é o único animal capaz de se espantar com a existência. Tal perplexidade se torna ainda mais séria, segundo 
o autor, quando ele se defronta com a morte. A ela, além disso, o homem é impingido constantemente pela finitude da existência e pela esterilidade de todo esforço. Em virtude desse espanto com o existir, de seu agravamento pelo conhecimento antecipado da morte, bem como daquilo que o acompanha, Schopenhauer define o homem como animal metaphysicum, como o único animal que possui necessidade de uma metafísica.

Tal espanto ou perplexidade, que constitui o fundamento das disposiçôes religiosa e filosófica, transforma em problema o universal do fenômeno - de modo diverso, por exemplo, dos cientistas, os quais se ocupam apenas com fenômenos selecionados e raros. A filosofia compromete-se com a compreensão do mundo de maneira puramente objetiva, isto é, em sua totalidade:

[...] a perplexidade filosófica que surge disso é condicionada no indivíduo por um desenvolvimento superior da inteligência, embora geralmente não apenas por ela; mas indubitavelmente é o conhecimento da morte, e ao seu lado a consideraçáo do sofrimento e miséria da vida, aquilo que fornece o mais forte impulso para a reflexão filosófica e para as explicaçôes metafísicas do mundo. Se a nossa vida fosse sem fim e sem dor, possivelmente não ocorreria a ninguém se questionar por que o mundo existe, e porque tem precisamente essa constituição, mas tudo seria entendido puramente como matéria de seu próprio curso. (MVR/WWV II $17,176-177){ }^{3}$

A "verdadeira filosofia" - o oposto da "filosofia catedrática" - está preocupada com o problema da existência, na medida em que esta se apresenta aos homens de forma "enigmática", sendo-lhes claras apenas a sua miséria e nadidade (Nichtigkeit).

A religião e a filosofia são, conforme indicado, as duas formas de satisfazer a necessidade metafísica do homem. Mas, antes: o que significa metafísica, em Schopenhauer?

\footnotetext{
${ }^{3} \mathrm{MVR} / \mathrm{WWV}$ é a abreviatura de $O$ mundo como vontade e como representação, Die Welt als Wille und Vorstellung, obra máxima de Schopenhauer, e o número em romano que se segue faz referência a qual volume (I ou II) da obra está sendo levado em conta. O número arábico indica o capítulo da obra em questáo, seguido pelo número da página da ediçâo canônica alemâ, mencionada na bibliografia. Foram utilizadas, no decorrer do presente texto, as traduçôes brasileiras dessas obras, conforme indicadas também na bibliografia. Em muitas ocasióes, contudo, especialmente em relação ao segundo volume de $O$ mundo como vontade e representação, as traduçôes são de minha autoria.
} 
Por metafísica eu entendo todo o suposto conhecimento que vai além da possibilidade da experiência, também para além da natureza ou da aparência das coisas dada fenomenicamente, de modo a dar uma explicação sobre aquilo por meio do qual, em um sentido ou outro, aquela experiência ou natureza é condicionada; ou, dito em linguagem popular, sobre aquilo que está oculto detrás da natureza e a torna possível. (MVR/WWV II 17, 180).

Os dois tipos de metafísica, a religião e a filosofia, diferenciam-se pelo fato de que a primeira tem as suas credenciais fora de si e a segunda as tem em si. As religióes possuem, enquanto "metafísica do povo", apenas uma verdade sensu allegorico, ou seja, não podem apresentar a verdade de modo tão direto quanto a filosofia, a qual possui verdade sensu proprio. Esses são alguns dos principais pressupostos do que Schopenhauer concebe como filosofia "imanente". Enquanto a religião busca a verdade fora de si, na transcendência, e a apresenta de modo alegórico, que é a maneira mais adequada para o público ao qual se destina, a filosofia busca em si mesma a verdade, isto é, recorre-se estritamente àquilo que é fornecido pela experiência humana e formula a partir dela os seus conceitos gerais. ${ }^{4}$ Em virtude disso, tal espécie de metafísica, restrita a poucos homens, é capaz de apresentar a verdade de modo mais direto, evidente e, em última instância, mais "real" que a religião. ${ }^{5}$

O enigma (Räthsel) da existência, do qual filosofia e religião se ocupam, consiste na percepção de que a existência é uma contingência - e não uma necessidade, como queria Spinoza. Isso significa, para Schopenhauer, que tanto a existência quanto a não-existência são igualmente possíveis:

\footnotetext{
${ }^{4}$ Não se trata aqui, como se sabe, de um empirismo ao modo de Hume, mas do desenvolvimento da filosofia crítica kantiana, de acordo com a qual o conhecimento se inicia, mas não deriva da experiência. Para Schopenhauer, assim como para Kant, só se pode conhecer as manifestaçôes (ou o fenômeno) da coisa em si, que se dá na experiência. É a partir dela que o conhecimento se torna possível, quando é permitido ao filósofo proceder às generalizações que caracterizam a sua forma de conhecimento. Embora não faça parte das pretensôes do presente texto tratar minuciosamente da teoria do conhecimento schopenhaueriana, tema assaz complexo e que excede os seus objetivos iniciais, voltarei ao tema, adiante.

${ }^{5}$ Vale destacar que a diferenciação entre as religiôes se dá fundamentalmente, para Schopenhauer, em função do quanto de verdade elas contêm em suas alegorias. As religiôes otimistas, como o islamismo, contêm muito pouca verdade. Já as pessimistas, como o cristianismo, o hinduísmo e o budismo, contêm uma quantidade maior de verdade, de tal sorte que elas se aproximam mais da verdade filosófica (cf. MVR/WWV II 17 p. 183-188).
} 
De fato, a inquietação que mantém em movimento o relógio da metafísica, o qual nunca para, é o claro conhecimento de que a não existência deste mundo é tão igualmente possível quanto a sua existência. Por isso, a visão de Spinoza do mundo como um modo de existência absolutamente necessário, em outras palavras, como algo que certamente e em todo sentido deveria e teria de ser, é falsa. Até mesmo o simples teísmo começa silenciosamente em sua prova inferindo a partir da existência do mundo a sua inexistência anterior: assim, ele assume antecipadamente que o mundo é algo contingente. (MVR/WWV II 17, 189).

O enigma do mundo se configura, em última instância, na pergunta pelo seu vir a ser, uma vez que o contrário seria igualmente possível: o mundo poderia simplesmente náo existir. O que faz com que o mundo venha a ser? $\mathrm{Na}$ sequência do texto, Schopenhauer leva adiante a pergunta da qual se origina a filosofia e apresenta a ideia de que a náo existência seria, inclusive, preferivel à existência:

$\mathrm{E}$, mais que isso, nós de fato concebemos muito brevemente o mundo como algo cuja não existência seria não apenas pensável, mas mesmo preferível à sua existência; por isso, a nossa perplexidade sobre ele chega, após reflexão, àquela fatalidade, que poderia contudo trazê-lo à existência, e em virtude da qual tal força imensa, que é requerida para a produção e manutençáo do mundo, poderia ser dirigida contra o seu próprio interesse e vantagem. (MVR/WWV II 17, 189-190).

A filosofia não poderia ser, com base nesse ponto de vista, qualquer forma de otimismo, ao modo de Leibniz. Ela surge precisamente de um olhar na desgraça e maldade do mundo: o argumento de Schopenhauer está fundamentalmente comprometido com a ideia de que a mera existência do mal, no mundo, implica a preferência pela sua não existência, pois, mesmo que houvesse uma parcela de felicidade igualmente grande no mundo, ou até mesmo que a parcela de mal fosse por ela superada, o mal do mundo náo poderia ser "compensado": isto é, o mundo seria, ainda assim, algo que deveria náo ser. Todavia, prossegue o autor, visto que o mundo veio a ser, não pode ter surgido do nada, "pois nada náo pode surgir de nada". E aqui estamos diante do ponto central da metafísica "imanente" de Schopenhauer: o germe e o núcleo do mundo, do qual ele vem a ser, é a vontade (Wille), por ele caracterizada como essencialmente sofrimento. Pode-se ter, nesse ponto, uma visão mais clara da posição de Schopenhauer sobre o impulso original que leva à filosofia: trata-se não apenas do espanto e da perplexidade pelos quais o homem é tomado, ao se 
perguntar pela origem da existência, mas sobretudo pela constatação de que ela é em si mesma sofrimento (cf. MVR/WWV II 17, 190).

Schopenhauer está, assim, atribuindo uma dimensão existencial à pergunta da metafísica, tal como formulada por Leibniz: "o mundo é enigmático porque o modo como ele nos é dado suscita a pergunta 'porquê (sic) alguma coisa em vez de nada?'. ” Essa é a posição de Constâncio (2013, p. 57):

Schopenhauer pergunta "por que razáo não existe absolutamente nada em vez de existir este mundo?” [...], e esta reformulação do enigma do mundo tem como implicação tratar-se nele não apenas de saber o que as coisas são, mas também de saber que valor lhes devemos atribuir. $\mathrm{O}$ mundo é enigmático porque o modo como ele nos é dado suscita a questáo de saber se há uma razão para ele existir - se ele é algo que deve existir ou algo que não devia existir. E esta pergunta é feita do ponto de vista do humano, da perspectiva da nossa existência. O mundo é algo que merece ou algo que não merece a nossa aprovação? Devemos negá-lo ou afirmá-lo? A nossa existência individual e, em geral, a vida humana neste mundo faz sentido ou é vã? Devemos negar ou devemos afirmar a existência - seja a nossa existência em particular, seja a existência em geral, a existência do todo de que fazemos parte? É este o enigma.

A Física, enquanto explicação causal do universo, pode ser apenas relativamente verdadeira, na medida em que não é capaz de explicar o enigma da existência (cf. MVR/WWV II 17, 191). Nesse sentido, não é possível uma "física absoluta", tal como pretende o naturalismo (cf. MVR/WWV II 17, 194-195). Daí a necessidade de a metafísica lhe oferecer tal suporte, ao lhe fornecer o verdadeiro princípio de todas as coisas.

\section{A importânCia da noçấo de “EXPERIÊNCIA” para o PRoblema do “ENIGMA” DA EXISTÊNCIA}

Qual é, não obstante, a fonte do conhecimento metafísico? De modo diverso daquilo que defende Kant, afirma Schopenhauer, a sua origem não está nos "meros conceitos", pois estes dependem de "percepçóes mais certas e definidas", as quais são conhecidas intuitivamente (cf. MVR/WWV II 17, 199). Todo conhecimento metafísico surge, dessa maneira, da experiência, dado que as únicas estruturas "puras" - i.e., sem origem empírica - de que dispomos são o espaço, o tempo e a causalidade, que constituem a "parte puramente formal da intuição" (cf. MVR/WWV II 17, 199). Não se trata, contudo, de qualquer 
forma de experiência ou, conforme dito anteriormente, de sua concepção epistemológica de vertente humiana. Procuremos compreender essa ideia de modo mais claro, uma vez que alguns de seus aspectos serão essenciais para a análise do fenômeno da compaixão, bem como da concepção de ordenação moral de mundo, conforme se encontram no pensamento de Schopenhauer.

Acusando de petitio principii a concepção kantiana segundo a qual a metafísica deve ser fundada em conceitos puros a priori, pois ela assume de modo antecipado que apenas aquilo que conhecemos previamente a toda experiência pode ser estendido para além da mesma, Schopenhauer afirma, de forma contrária, que o conhecimento metafísico surge precisamente da experiência:

Em verdade, a tarefa da metafísica não é a observação de experiências singulares, mas sim a explicação correta da experiência em seu todo. O fundamento da metafísica, portanto, tem de ser de tipo empírico. Sim, inclusive a APRIORIDADE de uma parte do conhecimento humano é por ela apreendida como um FATO dado, do qual ela infere a origem subjetiva dessa parte. E precisamente só na medida em que a consciência da sua aprioridade acompanha o conhecimento, é que este, em Kant, chama-se TRANSCENDENTAL, à diferença de TRANSCENDENTE, que significa "para além da possibilidade de toda experiência", e tem como seu oposto IMANENTE, isto é, que permanece nos limites daquela possibilidade [...]. Ademais, a fonte de conhecimento da metafísica não é apenas a experiência EXTERNA, mas também a INTERNA. (MVR/ WWV II 17, p. 201. Trad. de Jair Barboza).

Para Schopenhauer, é possível conhecer a natureza das coisas tão somente por meio de uma investigação direta das mesmas, em oposição à recorrência a meros conceitos abstratos. E, dado que a metafísica não consiste, de fato, na observaçáo de experiências particulares - com o que o autor está de acordo com Kant -, mas na explanação da experiência como um todo (Erfahrung im Ganzen), o seu fundamento deve ser de natureza empírica. Todavia, o que significa tal fundamento empírico? Ao definir a sua metafísica como "imanente", como um conhecimento que permanece dentro dos limites possíveis da experiência, Schopenhauer nos fornece indícios de resposta a tal questão, como demonstrado na citação acima: a fonte do conhecimento da metafísica não é apenas a experiência externa, mas precisamente também a interna. A característica mais peculiar dessa metafísica é, segundo o autor, a sua capacidade de combinar essas duas formas de experiência, de tal modo a tornar a experiência interior a chave para a exterior. 
Se as experiências particulares e individuais são aquelas que, por serem sempre modificáveis, permitem o avanço das ciências, a experiência em geral (Erfahrung überhaupt), que nunca se modifica e é o objeto da metafísica, é o que lhe possibilita ir além da experiência comum, a experiência científica: "o todo da experiência se compara a um criptograma e a filosofia é a sua decifração, cuja exatidão é garantida pela coesão daquilo que aparece em todos os lugares." (MVR/WWV II 17, p. 202-203). A condiçáo para que tal criptograma possa ser interpretado e explicado a partir de si mesmo é que o todo da natureza seja captado em sua profundidade, bem como que a experiência interior seja conectada à exterior. Dessa maneira, "a ponte pela qual a metafísica transcendeu a experiência nada mais é que a distinção entre fenômeno e coisa em si." Tal distinção contém, segundo Schopenhauer, a prova de um núcleo do fenômeno, que é, contudo, diferente do fenômeno em si mesmo. Esse núcleo, acrescenta o autor, não pode jamais ser separado do fenômeno e considerado em si mesmo como um ens extramundanum: ele é conhecido tão-somente em suas relaçôes e referências ao fenômeno. É essa a única forma pela qual, de acordo com o filósofo, se faz possível obter informaçôes sobre a relação entre o fenômeno e o seu núcleo, que, de outro modo, não estão presentes na consciência humana. A metafísica vai além do fenômeno apenas em tal sentido, ao considerar de forma diferenciada aquilo que aparece no fenômeno, mas que de modo algum é dele independente como queria Kant, sobretudo.

Tão somente a interpretação e exegese desta [da aparência mesma, W.P.], em referência àquele seu núcleo íntimo, pode nos dar um esclarecimento sobre ela, o qual do contrário jamais chegaria à consciência. É nesse sentido, portanto, que a metafísica vai mais além da aparência, isto é, da natureza, até aquilo escondido atrás dela [...], considerando-o, entretanto, sempre apenas como aquilo que nela aparece, e não como algo independente de toda aparência: a metafísica, conseguintemente, permanece imanente e jamais será transcendente [...]. A metafísica [...] é ciência da experiência: no entanto, seu objeto e sua fonte náo são experiências particulares, porém o todo universal de qualquer experiência. Faço valer inteira e completamente a doutrina de KANT de que o mundo da experiência, precisamente como aparência, é manifestação daquilo que aparece, e que denomino, com Kant, de coisa em si. Essa coisa em si, em consequência, tem de exprimir sua essência e seu caráter no mundo da experiência, logo, estes têm de ser interpretados a partir daquela, e em verdade a partir do estofo e não da mera forma da experiência. Em consequência, a filosofia nada é senão a compreensão correta e universal da experiência mesma, a exegese verdadeira do seu sentido e conteúdo (MVR/WWV II 17, p. 203204. Trad. de Jair Barboza). 
Schopenhauer parte, portanto, da filosofia crítica de Kant, e lhe atribui o mérito de, enquanto filosofia "transcendental", ter-se contraposto à filosofia dogmática - e suas veritates aeterne (cf. MVR/WWV I "Crítica da filosofia kantiana”, p. 498-499). Kant não teria deduzido, contudo, a coisa em si de maneira correta, pois, conforme exposto acima, não conferiu à experiência a sua devida função nesse processo. E isso muito em virtude de não ter distinguido o conhecimento intuitivo do conhecimento abstrato, ao que o filósofo atribui as contradiçóes de seu sistema (MVR/WWV I, cf. p. 511).

Kant, conforme Schopenhauer, teria evitado uma série de problemas, se tivesse levado a cabo a distinção acima mencionada. O "objeto da experiência" não é, tal como apresentado pelo filósofo de Königsberg, a representação intuitiva, mas também não é o conceito abstrato; e, no entanto, é "os dois ao mesmo tempo" (MVR/WWV I, p. 518). O filósofo defende aqui, assim, um conceito inflacionado de intuição, no sentido de que esta tem uma função mais relevante no processo de conhecimento do que aquela atribuída na obra de Kant. Em meio aos seus elogios à Estética Transcendental, Schopenhauer pondera, contudo, que o que se esperava, após a discussão sobre as formas universais da intuição (i.e., o espaço e o tempo), seria um esclarecimento sobre o seu conteúdo, "a maneira como a intuição EMPÍRICA chega à nossa consciência, e como nasce o nosso conhecimento de todo este mundo, tão real e importante para nós." O que ocorre, entretanto, é o uso excessivo da expressão - vazia, aos olhos de Schopenhauer - "o empírico da intuição é DADO de fora." Kant, além disso, das formas puras da intuição, chega "por um salto ao PENSAMENTO, à LÓGICA TRANSCENDENTAL.” (MVR/ WWV I, p. 519).

A distinção entre conhecimento intuitivo e abstrato ter-lhe-ia evitado o equívoco de afirmar que nossas duas fontes de conhecimento são a "receptividade das impressôes" ("capacidade de receber representaçôes"; por ela "um OBJETO nos é dado") e a "espontaneidade dos conceitos" ("capacidade de conhecer um objeto por meio destas representaçóes"; por ela um objeto é "pensado”) ${ }^{6}$, pois, segundo Schopenhauer, a intuição não só é em si mesma já conhecimento, como também é a principal de suas formas:

6 Schopenhauer cita aqui um trecho da Crítica da razão pura. 
[...] a impressão não passa de uma mera SENSAÇÃO no órgão dos sentidos, e só pela aplicação do ENTENDIMENTO (isto é, da lei da causalidade) e das formas da intuição do espaço e do tempo é que nosso INTELECTO converte essa mera SENSAÇÃO em uma REPRESENTAÇÃO, que, doravante, existe como OBJETO no espaço e no tempo e não pode ser distinguida deste último (o objeto), exceto se perguntarmos pela coisaem-si; do contrário, é idêntica ao objeto [...]. Com isso está cumprida a tarefa do entendimento e do conhecimento intuitivo e, para tal, não foi preciso conceito algum nem pensamento; eis por que também o animal possui essas representaçóes. Se conceitos, o pensamento é acrescentado, ao qual, decerto, espontaneidade pode ser atribuída, o conhecimento INTUITIVO é totalmente abandonado e uma classe por inteiro diferente de representaçôes, a saber, não intuitivas, conceitos abstratos, entra na consciência. Eis aí a atividade da RAZÃO que, no entanto, tem todo o conteúdo de seu pensamento unicamente a partir da intuição que o precede e da comparaçáo dele com outras intuiçóes e conceitos. Porém Kant traz o pensamento já para a intuição e, assim, assenta a fundaçáo para a mistura nociva entre conhecimento intuitivo e abstrato [...] (MVR/ WWV I, p. 520).

Se, para Kant, há apenas conceitos de objetos - e não intuições dos mesmos -, para Schopenhauer, ao contrário, "objetos existem primariamente apenas para a intuição, e conceitos são sempre abstrações dessa intuição.” É em virtude dessa importância do conhecimento intuitivo que o autor sugere que se descartem onze das doze categorias de Kant, mantendo-se tão somente a causalidade: enquanto condição da intuição, a única categoria admitida por Schopenhauer nos indica que a intuição "não é meramente sensual, mas intelectual, e que o objeto assim intuído, o objeto da experiência, é uno com a representação, da qual ainda deve ser distinguida só a coisa-em-si." (MVR/ WWV I, p. 531).

A teoria do conhecimento ocupa, desse modo, um papel preponderante no sistema filosófico schopenhaueriano. ${ }^{7}$ Há, de acordo com a sua concepção,

7 Essa afirmação pode ser comprovada explicitamente nos textos do próprio autor. Nos Parerga e Paralipomena (doravante PP), Schopenhauer, ao tratar da "experiência mesma" como o verdadeiro objeto da filosofia (e não "essa ou aquela experiência determinada", tampouco "conceitos puros e abstratos"), determina que a primeira coisa que a filosofia deve considerar é o "medium pelo qual a experiência em geral se apresenta a si mesma: o intelecto." "Dessa forma", afirma o autor, "toda filosofia deve começar com uma investigação sobre a faculdade de conhecimento, suas formas e leis, assim como de sua validade e seus limites. Uma tal investigação será a philosophia prima. Ela se divide, de um lado, na consideração das representações primárias, isto é, intuitivas, parte que recebe o nome de Dianologia ou teoria do entendimento; e de outro, na consideração das representaçóes secundárias, isto é, abstratas, assim como da ordenação de seu uso, formando assim a lógica ou a teoria da razão. 
três faculdades cognitivas humanas: a sensibilidade (Sinnlichkeit), o entendimento (Verstand) e a razão (Vernunft). O entendimento, faculdade compartilhada por animais humanos e não-humanos, é o responsável pela transformação, via causalidade, das meras sensaçóes recebidas pela sensibilidade em intuiçóes. Cabe à razão, por fim, apenas a tarefa de organizar, via conceitos abstratos, o diverso infindo dos fenômenos intuitivos, de tal sorte que, ordenado em um sistema, tal conhecer (Wissen) explica o que ocorreu precedentemente e determina o que virá a ocorrer no futuro. $\mathrm{O}$ todo desse processo é denominado por Schopenhauer conhecimento (Erkenntnis).

Pode-se compreender de modo mais claro, a partir do que foi discutido, a concepção schopenhaueriana de metafísica: ela não é transcendente (i.e., não se recorre, no processo de fundamentação de sua teoria, a qualquer instância que esteja para além da experiência) e nem propriamente transcendental (i.e., não tem por foco especial, tal como na filosofia crítica de Kant, as estruturas que são a condição de possibilidade do conhecimento), mas é imanente - é uma metafísica que, a fim de dar conta de uma explicaçáo do todo do universo, lança mão fundamentalmente da experiência e, mais especificamente, da experiência levada a cabo no conhecimento intuitivo.

Entendidas, portanto, como estofo de nosso pensamento, as intuiçóes são, sem sombra de dúvidas, a principal fonte de conhecimento humano. Dada a função central das intuições na teoria do conhecimento schopenhaueriano e, sobretudo, dada a função central da teoria do conhecimento no sistema filosófico do autor como um todo, torna-se não apenas profícua, mas também necessária, uma discussão sobre a relação entre o conhecimento intuitivo e o fenômeno da compaixão (Mitleid), uma vez que este é descrito pelo filósofo como um tipo de "experiência" e, por conseguinte, como uma determinada forma de conhecimento intuitivo. Buscaremos compreender mais adequadamente, na sequência, a dimensão ética do sistema schopenhaueriano, em sua relação de interdependência com a sua concepção de metafísica imanente.

Essa parte geral compreende, ou melhor, substitui ao mesmo tempo aquilo que outrora se chamava Ontologia, que compunha a teoria das propriedades mais universais e essenciais das coisas em geral enquanto tais. Pois se considera como propriedades das coisas em si mesmas o que somente pertence a elas em consequência da forma e da natureza de nossas faculdades representativas, já que todos os seres que essas apreendem devem se exibir de acordo com a forma e natureza da nossa faculdade representativa e, por isso, deve trazer em si certas propriedades comuns a todas elas. Isso se compara ao ato de atribuir uma cor aos objetos a partir da lente pela qual vemos." (PP II, p. 23). Essa discussão será fundamental na concepção da ética no sistema schopenhaueriano, na medida em que apenas por uma determinada forma de conhecimento da dor do outro é que se pode alcançar a virtude e, em um grau mais avançado, a liberdade. Esse ponto será trabalhado na sequência do texto. 


\section{Aspecotos CENTRAIS DA DOUTRINA DA VIRTUdE E DA SOTERIOLOGIA}

O que significa tal "experiência" da compaixáo? Em que medida ela está relacionada à concepção de uma metafísica "imanente"? Contrário à possibilidade de uma filosofia prática (afinal, para ele, toda filosofia é sempre teórica), Schopenhauer desenvolve uma ética descritiva - quer dizer, uma ética que não se ocupa em moralizar os homens, mas em analisar o fenômeno ético. Isso se dá em função do fato de que a vontade, essência metafísica do universo, só é autônoma enquanto coisa em si, com o que é impossível moldar o caráter humano (em outras palavras e se valendo da terminologia do autor, o "caráter empírico" do homem nada mais é que a manifestação de seu "caráter inteligível”) (cf. MVR/WWV I 53; cf. também p. 342-344).

Todas as mudanças ocorridas no mundo empírico seguem, segundo Schopenhauer, uma causa suficiente. No plano das açóes, tal causa suficiente é chamada de motivo (Motiv). Há, de acordo com o autor, duas espécies de motivos, cada uma das quais constituindo uma forma diversa de conhecimento: as representaçôes intuitivas, pelas quais são movidos os animais não-humanos, e as representaçóes abstratas, que, ao lado das anteriores, movem os homens, já que estes são providos de razão. Os motivos que guiam os animais humanos e não-humanos à ação são determinados por aquilo que é "bom" (Gut) ou "mau" (Böse), pelo objeto que, respectivamente, está ou não está em conformidade com algum esforço determinado da vontade: ou seja, "bom” é aquilo que está em conformidade com a minha vontade, "mau” é aquilo que não está em conformidade com a mesma (cf. MVR/WWV I 65). É dos conceitos de Gut e Böse que surgem, por sinal, todos os sistemas éticos, tanto os filosóficos quanto os religiosos. O equívoco de todos eles consiste em vincular felicidade e virtude: por definição, a virtude deve ir, conforme Schopenhauer, precisamente na direção oposta da felicidade.

O conceito schopenhaueriano de virtude é melhor compreendido na sua relação com os móbiles das açóes humanas, de maneira que o seu significado se torna mais claro não apenas para o sistema ético do autor, mas também, e sobretudo, para a sua concepção de metafísica, principal alvo do presente texto. Quando um homem age visando exclusivamente afirmar a própria vontade, percebe-se nele um caráter egoísta (cf. MVR/WWV I 61). O egoísmo é o primeiro e mais básico dos móbiles das ações humanas, pois ele é compartilhado também com os animais não-humanos, além de representar, em primeiríssima instância, o próprio movimento de objetivação da vontade cósmica no plano empírico. O caráter maldoso - e, em um grau mais extremo, 
o cruel - é aquele que não se vale do sofrimento alheio somente como meio para atingir os fins da própria vontade, como ocorre no caráter egoísta, mas toma o sofrimento alheio como fim em si mesmo. A maldade e a crueldade constituem, desse modo, o segundo móbile das açóes humanas, momento em que o sofrimento já passa a figurar explicitamente como o principal tema da ética schopenhaueriana (cf. SFM/BM 14). ${ }^{8}$

O "simples moralizar", aos moldes de Kant, não faz qualquer efeito sobre o caráter dos homens, pois ele não "motiva". Uma moral que motiva só pode fazê-lo, segundo Schopenhauer, atuando sobre o amor próprio. $\mathrm{O}$ que dele nasce, contudo, não tem valor moral algum, porque se trata apenas da mudança de direçấo da vontade, que em nada afeta o sofrimento causado pela manifestação da essência do universo. A concepção de uma "virtude autêntica" surge, assim, do conhecimento intuitivo da vontade, "o qual reconhece no outro indivíduo a mesma essência que a própria.” (cf. MVR/ WWV I 66, p. 435-437).

Schopenhauer busca, a partir desse ponto de vista, fundamentar (begründen) a moral. Esse é, em sua visão, o grande problema da filosofia moral, e é precisamente nessa empreitada que reside a falha do projeto racionalista kantiano, pois o pensador não teria reconhecido no sofrimento o principal problema da ética, tampouco teria atribuído a devida importância ao conhecimento intuitivo no processo de fundamentação da moral.

O critério das açôes dotadas de valor moral é determinado pelo autor em sua análise de alguns seres de exceção, nos quais ocorre a "exclusão daquela espécie de motivos, por meio dos quais [...] procedem todas as açóes humanas, a saber, o interesse próprio." (SFM/BM 15). ${ }^{9}$ A ausência de toda motivação egoísta é, desse modo, o critério buscado por Schopenhauer para a sua fundamentação da moral. De onde brotam, contudo, as ações dotadas de valor moral, tais como as de "justiça espontânea" e "caridade desinteressada"?

8 SFM/BM abrevia Sobre o fundamento da moral, Über das Fundament der Moral, texto publicado em 1840 por Schopenhauer. Os números arábicos indicam o número do capítulo da obra, seguidos pelo número da página da edição alemã.

${ }^{9}$ Diante da possível objeção de que as açōes maldosas não săo interessadas e que, portanto, se enquadrariam no critério acima estabelecido como o único dotado de valor moral, Schopenhauer acrescenta ainda mais dois critérios, os quais lhe servem de suporte, ao expressarem a repulsa do homem moral também às ações maldosas: o "aplauso de consciência", o fato de que as açóes dotadas de valor moral "deixam ficar um certo contentamento com nós mesmos"; e, como "marca externa e acidental", "o aplauso e o respeito das testemunhas que não participam delas." No caso de açóes maldosas, tais apreciações ocorrem de modo precisamente oposto (cf. SFM/BM 15, p. 674). 
A resposta do filósofo é encontrada em suas análises do terceiro móbile das açôes humanas, a compaixão: como uma forma de "amor puro" (reine Liebe [caritas]) - e, portanto, como o extremo oposto do amor próprio -, a compaixão conduz o homem ao conhecimento do sofrimento alheio (cf. MVR/WWV I 67).

Nesse ponto, fica mais clara a razão pela qual a ética schopenhaueriana pode ser denominada uma ética do sofrimento (Leidensethik): podendo o mundo ser compreendido em si mesmo como um acontecimento do sofrimento (Leidensgeschehen), uma vez que é a manifestação da essência metafísica do universo - a qual é, por definição, dor -, uma ética tem de dar conta fundamentalmente do problema de como lidar com a dor e o sofrimento (cf. HALLICH, 2014, p. 77-78). ${ }^{10}$ Daí o autor se recorrer ao critério do interesse próprio: na medida em que o homem consegue romper o egoísmo que caracteriza as ações de todos os animais, ele alcança, via conhecimento intuitivo, a compreensão de que todos os seres do mundo são frutos de uma e mesma essência, que é em si sofrimento. Tal identificação com a dor do outro, de sorte que não haja mais qualquer diferença entre os indivíduos pelo menos do ponto de vista do compassivo -, se dá, deve-se destacar, pelo conhecimento que se tem do outro, visto que um homem náo pode ter acesso ao corpo de outrem.

Atente-se aqui, mais uma vez, ao papel central ocupado pelo conhecimento intuitivo, não circunscrito apenas ao campo da epistemologia, mas ampliado também, nesse contexto, para o campo da ética. Tal tese ganha tamanha envergadura no pensamento de Schopenhauer que o autor fornece indícios de sua influência no pensamento oriental, ao caracterizar a compaixão como "uma ação misteriosa, uma mística prática” e, por conseguinte, "o maior mistério da ética.” (SFM/BM 22). A compaixão, para além de ser o fundamento da moral buscado pelo filósofo, é investida, ademais, de uma função metafísica essencial, já que ela permite o rompimento do principium individuationis e, principalmente, abre caminho para a negação completa da vontade, no ascetismo.

\footnotetext{
${ }^{10} \mathrm{O}$ próprio Schopenhauer admite explicitamente essa ideia. Ao apresentar as provas "empíricas" da única motivaçáo moral genuína, a compaixão, o autor afirma que a compaixão se manifesta de maneira mais evidente na caridade do que na justiça, e atribui isso ao fato de que os homens se inclinam, se tornam compassivos, às pessoas em situação de sofrimento: "o homem mais feliz pode experimentar de muitos modos o bem-querer de seus parentes e amigos. Porém as manifestações daquela participação pura, desinteressada e objetiva no estado e destino alheios que são efeitos da caridade ficam reservados para quem está sofrendo sob algum aspecto. Pois não nos interessamos por aquele que, como tal, é feliz, mas antes este permanece, como tal, alheio ao nosso coração.” (SFM/BM 19, p. 707).
} 
A ascese é, para Schopenhauer, uma espécie de "melhor intelecção" (bessere Einsicht), capaz de eliminar aquilo que é por nós exigido e aquilo que nos é dado. Trata-se de um melhor emprego da razão, se comparado àquele que gera o conhecimento abstrato, na medida em que ela "pode livrar-nos de todo fardo e sofrimento da vida e conduzir-nos à bem-aventurança." (MVR/WWV I 16, p. 108). Isso só é possível graças a uma combinação entre razão e intuição, de maneira que a melhor intelecção é a contrapartida, no que diz respeito à razão, do conhecimento abstrato. A transição da virtude, da compaixão, à ascese se dá no momento em que o ultrapassamento do principium individuationis pelo compassivo, ao reconhecer a dor alheia como a sua própria, gera tal espécie de conhecimento, a melhor intelecção, que funciona como um quietivo da vontade (cf. MVR/WWV I 68, p. 448-449). Apenas nesse momento se pode falar em liberdade da vontade no pensamento do autor, impossível a qualquer homem que esteja agindo sob quaisquer formas de motivação - mesmo a compassiva. Schopenhauer mobiliza o conceito de ascese, desse modo, no intuito de tornálo o corolário de sua metafísica da vontade, como uma espécie de realizaçáo intuitiva da verdade do pessimismo que caracteriza o seu pensamento (cf. YOUNG 1988, p. 98), como uma espécie de redenção e salvação do sofrimento que caracteriza a essência do universo.

Como se pode notar, tanto em sua doutrina da virtude quanto em sua soteriologia, Schopenhauer confere uma funçáo essencial ao conhecimento sobretudo ao conhecimento intuitivo -, na medida em que é por meio dele que se tem acesso à vontade. Ambas desempenham, assim, um papel essencial na sua decifraçáo do enigma do mundo, isto é, em sua metafísica. Parece-me, contudo, que o autor faz um uso estratégico do estatuto epistemológico da experiência, em sua metafísica, nos termos anteriormente discutidos, a fim de ampliar o seu estatuto também para o âmbito da moralidade, de tal forma que estabelece uma espécie de inter-relação entre os âmbitos epistemológico, moral e metafísico de seu pensamento. Procuro desenvolver essa tese, na sequência, ao discutir as implicaçóes da vinculação entre metafísica e ordenaçấo moral de mundo em Schopenhauer.

\section{METAFÍSICA E ORDENAÇÃo MORAL DE MUNDO: A QUESTÁO DA JUSTIÇA ETERNA}

A doutrina da virtude e da soteriologia desempenham, portanto, uma função central no projeto schopenhaueriano de decifraçáo do enigma do mundo, a qual cabe, como já sabemos, principalmente à metafísica. $\mathrm{O}$ autor ainda a vincula, todavia, a outro problema, de grande envergadura em seu 
pensamento: o da ordenação moral de mundo. Mesmo em um escrito como Sobre o fundamento da moral, cujo objetivo é apresentar provas de ordem empírica para as duas virtudes cardeais de sua filosofia, a justiça e a caridade, Schopenhauer não se furta de estabelecer, desde o início da obra, a vinculação entre a sua fundamentação da moral e a sua concepção de metafísica. ${ }^{11}$

\section{O fato de que o fundamento da moral deve ser encontrado separadamente} de qualquer sistema filosófico - ou seja, da metafísica propriamente dita - torna tal tarefa, admite o autor já na "Introdução", não apenas difícil, mas necessariamente incompleta. Apoiando-se em Wolff, segundo o qual a metafísica ilumina as trevas da filosofia prática, e em Kant, para quem a metafísica é a condição sine qua non da filosofia moral, Schopenhauer afirma que, "na filosofia, qualquer que seja o seu fundamento ético, ele deve ter, por sua vez, seu ponto de apoio e sua base em alguma metafísica, quer dizer, na explicação do mundo e da existência em geral":

Pois a última e verdadeira elucidação sobre a essência interna do todo das coisas tem de estar necessária e estreitamente ligada com aquela que expressa o significado ético do comportamento humano, em todo o caso, com aquilo que é estabelecido como fundamento da moral; se não for uma mera proposição abstrata que paira livre no ar, sem apoio no mundo real, tem de ser algum fato existente, ou no mundo real, ou na consciência humana, que, como tal, pode ser ainda fenômeno e por isso solicitar, como todo fenômeno do mundo, maiores explicaçôes que, então, seráo exigidas da metafísica. A filosofia é, em geral, um todo de tal modo coerente que é impossível expor exaustivamente qualquer parte dela sem que todo o resto a acompanhe. (SFM/BM 1, p. 579).

\footnotetext{
${ }^{11} \mathrm{O}$ escrito de 1840 foi redigido, como se sabe, em resposta à pergunta colocada pela Sociedade Real Dinamarquesa de Ciências de Copenhague sobre a necessidade com a qual surge a "ideia originária da moralidade ou do conceito principal de lei moral suprema" e sobre onde eles se apresentam, "em parte no juízo da consciência sobre nossas próprias açóes, em parte em nossos juízos morais sobre o comportamento dos outros": "a fonte e o fundamento da filosofia moral devem ser buscados numa ideia de moralidade contida na consciência imediata e em outras noçóes fundamentais que dela derivam ou em outro princípio do conhecimento?" (SFM/BM, p. 575-576). Daí a frase de Sobre a vontade na natureza (Ueber den Willen in der Natur), apresentada como mote por Schopenhauer no início do texto, em clara oposição a Kant e à moral deontológica, em geral: "pregar a moral é fácil, fundamentar a moral é difícil". O objetivo do filósofo no escrito em questáo é, por conseguinte, fundamentar aquilo que conduz, no plano empírico, à justiça e à caridade. Tal fundamento, defende o autor, não pode ser obtido por "combinaçóes artificiais de conceitos de qualquer espécie", mas, pelo contrário, tem de ser algo "que fale a todo homem, mesmo o mais tosco, repousando meramente na apreensão intuitiva e impondo-se imediatamente a partir da realidade das coisas." (SFM/BM 12, p. 656). É precisamente em suas análises daquilo em que consiste a apreensão intuitiva e a realidade das coisas que, conforme veremos, reside o vínculo entre sua fundamentação "empírica" e "metafísica" da moral.
} 
A tese de Schopenhauer, nesse ponto, é a de que as metafísicas da natureza, dos costumes e do belo se pressupóem de modo recíproco e de que somente em seu conjunto fornecem uma "explicação sobre a essência das coisas e sobre a existência em geral.” Tal concepção nos fornece indícios do modo como o autor compreende a própria noção de metafísica imanente - segundo a qual as partes estão de tal maneira interligadas, que o todo é concebível apenas a partir da relação entre elas -, porém, deixa escapar uma ideia fundamental, que permanece nas entrelinhas do texto: tal explicação do mundo e da existência em geral, a qual serve de suporte metafísico à fundamentação da ética, é ela mesma uma concepção ética, de sorte que a própria ética também parece conferir significado à metafísica - e não apenas o contrário. Eis a tese que vem sendo construída desde as linhas iniciais do presente texto e que nos servirá de base para estabelecer o escopo e o alcance de outro conceito fundamental na concepção ético-metafísica da existência pelo autor, qual seja, o de "justificação da existência".

Ao mesmo tempo em que Schopenhauer afirma que o fundamento da ética pode ser encontrado sem remissão à metafísica, ele admite, nos capítulos que redige como suplemento à obra em questão, não apenas (i) que é necessário remontá-lo à mesma, no intuito de compreender o "fenômeno originário" donde tudo se segue ${ }^{12}$, mas também, e sobretudo, (ii) que "o último cume a que em geral acede o significado da existência é indubitavelmente o ético." (SFM/BM 21, p. 731). Enquanto, em seu projeto de fundamentação da moral, o autor examina o compassivo em sua relação com os outros - isto é, procede por via empírica -, a sua análise do compassivo, quando tomado em si mesmo, é o que lhe fornece o significado metafísico da ética. Nesse ponto, Schopenhauer lança mão da ideia de que o compassivo "faça menos diferença entre si e os outros que as demais pessoas" (SFM/BM 22, p. 735), no intuito de demonstrar a apreensão do "eu" do outro como aquilo que comprova o fundamento metafísico da compaixão. ${ }^{13}$ A compaixão "seria", desse modo, "a base metafísica da ética e constituiria no fato de que um indivíduo se reconhece a si próprio, a sua essência verdadeira, imediatamente no outro":

\footnotetext{
12 "Como no final de toda pesquisa e de toda ciência real, também aqui o espírito está diante de um fenômeno originário que esclarece tudo o que é compreendido sob ele e o que dele se segue, mas ele próprio permanece inexplicável e apresenta-se como um enigma. Portanto, aqui também coloca-se a exigência de uma metafísica [...]" (SFM/BM 21, p. 730-731).

${ }^{13}$ Tal apreensão do outro pelo compassivo é diversa daquela pelo egoísta, na medida em que esta é "empiricamente justificada" pelo fato de que "a diferença entre a própria pessoa e a pessoa alheia aparece como sendo absoluta, de acordo com a experiência": "a diferenciação do espaço que me separa do outro separa-me também do seu bem e mal-estar.” (SFM/BM 22, p. 736).
} 


\begin{abstract}
A individuação é o mero fenômeno que nasce mediante o espaço e o tempo, que não são nada além de formas de todos os objetos condicionados por meio de minha faculdade cerebral de conhecimento. Por isso, também a multiplicidade e a diferenciação dos indivíduos é um mero fenômeno, quer dizer, só está presente na minha representação. Minha essência interna verdadeira existe tão imediatamente em cada ser vivo quanto ela só se anuncia para mim, na minha autoconsciência." Este conhecimento, para o qual, em sânscrito, a expressão corrente é "tat-tvam-asi”, quer dizer, "isto és tu", é aquilo que irrompe como compaixão, sobre a qual repousa toda virtude genuína, quer dizer, altruísta, e cuja expressão real é toda ação boa. Este conhecimento é aquele pelo qual, em última instância, dirigem-se todos os apelos à doçura, à caridade, à clemência, pois é uma lembrança da consideraçáo de que todos nós somos uma e a mesma essência. (SFM/ BM 22, p. 740-741. Cf. também MVR/WWV II 47, p. 686-687, onde o autor trata da natureza tal como se manifesta no indivíduo e do ponto de vista universal).
\end{abstract}

As reflexôes morais são, sob esse ponto de vista, as mais importantes no pensamento de Schopenhauer, pois, de acordo com o próprio autor, elas concernem imediatamente à coisa em si e, além disso, proporcionam o consolo de que necessita a nossa existência, uma vez que no campo moral "as profundezas de nossa própria natureza interior se abrem à consideração." (MVR/WWV II 47, p. 674).

Desde Sócrates, o problema da filosofia é, segundo Schopenhauer, "estabelecer um vínculo entre a força que produz o fenômeno do mundo, e em consequência determina a sua natureza, e a moralidade do etos, e assim demonstrar uma ordenação moral de mundo [moralische Weltordnung] como a base da [ordenação, W.P.] física." (grifos meus). Se o teísmo falhou nessa empreitada, ao se portar "de modo infantil", o panteísmo, ainda que, em oposição ao teísmo, tenha demonstrado que a natureza traz em si mesma a força pela qual tal vínculo vem a ser, acaba por cair no equívoco de náo deixar espaço para uma ética em sua visão de mundo, ou seja, para o problema da desgraça e do sofrimento da existência: pois, se tudo o que é produzido é divino e primoroso, nada pode ser mais valioso que nada, assim como nada pode ser mais censurável que nada, com o que não haveria mais ética (cf. MVR/WWV II 47, p. 675ss.).

Schopenhauer crê ter dado uma solução ao problema colocado por Sócrates, na filosofia, ao desenvolver uma ética "ateísta", baseada na vontade e no indivíduo: a questão que concerne à ética, afirma o autor, não é a da ação 
e do resultado, mas a do querer, o qual ocorre apenas no indivíduo - apenas indivíduos existem, enquanto naçóes, por exemplo, são meras abstraçóes do movimento de objetivação da vontade que ocorre naqueles. Se a vontade é em si mesma sofrimento e se, por conseguinte, o seu movimento de objetivação nos indivíduos nada mais pode causar que sofrimento, o objeto da ética só pode ser, conforme demonstrado anteriormente, o sofrimento. Tanto o teísmo, com seus "pretextos e teodiceias", quanto o panteísmo, e sua impossibilidade de desenvolver uma ética, falharam na tentativa de dar uma solução ao problema do sofrimento. Desse modo, afirma Schopenhauer, somente quando se considera o mundo "inteiramente de fora e somente do lado físico" é que se pode compreender a ordenação de todas coisas, as quais se renovam constantemente, e, portanto, também a "imperecibilidade do todo". É a partir desse ponto de vista que o filósofo pretende demonstrar a ordenação moral de mundo:

[...] a força que opera e atua na natureza é idêntica à vontade em nós mesmos. Desse modo, a ordenação moral de mundo entra efetivamente em conexão direta com a força que produz o fenômeno [Phänomen] do mundo. Pois o fenômeno [Erscheinung] da vontade deve corresponder exatamente à sua natureza: nisso se baseia a explanação da justiça eterna [ewige Gerechtigkeit] [...]; e, embora continue a existir pelo seu próprio poder, o mundo recebe ininterruptamente uma tendência moral. Consequentemente, o problema colocado desde o tempo de Sócrates é pela primeira vez realmente resolvido e a exigência de nossa razão pensante, direcionada àquilo que concerne à moral, satisfeita. (MVR/WWV II 47, p. 676-677).

Se a ideia de uma ordenação moral de mundo é, em certa medida, como acaba de ser comprovado, uma extensão do entendimento schopenhaueriano da compaixão enquanto fundamento da moral, o próprio autor indica, na passagem acima, o conceito-chave de todo esse projeto: o de justiça eterna. ${ }^{14}$

\footnotetext{
${ }^{14} \mathrm{O}$ leitor é aqui remetido, mais uma vez, portanto, ao conceito schopenhaueriano de justiça (Gerechtigkeit). Um primeiro sentido do termo já foi discutido no contexto de sua doutrina da virtude, a saber, nas açôes de "justiça espontânea". O filósofo trata, ainda, de outros dois sentidos do mesmo: a justiça temporal e a justiça eterna, esta o motivo da incursão do presente texto na concepção de justiça do filósofo de Danzig. A justiça temporal (zeitliche Gerechtigkeit) é concebida como o conceito negativo de injustiça (Unrecht), esta consistindo na "invasão dos limites da afirmação alheia da vontade." (MVR/WWV I 62, p. 394). Justo (Recht) significa a possibilidade de negar, "com justiça", a negação da vontade alheia, com a força necessária para a sua supressão (cf. idem, p. 401). Uma doutrina do Direito (Rechtslehre) se restringe exclusivamente à prática da justiça ou injustiça, uma vez que ela se refere apenas ao fazer, e náo ao sofrer. O Direito Penal tem em vista, nesse contexto, evitar a ocorrência de açôes injustas em um tempo futuro. O Estado, por fim, que tem por função a punição da invasão da afirmação da vontade alheia, é a sede da justiça temporal e visa a garantir a execuçáo do Direito Penal (cf. idem, p. 410-411).
} 
Esta, enquanto forma de elevação sobre o conhecimento fornecido pelo princípio de razão, consiste fundamentalmente na percepção de que as formas do fenômeno não concernem à coisa em si, de tal modo que se dá conta de que a diferença entre quem causa e quem padece do sofrimento é apenas de ordem fenomênica, não atingindo o movimento de objetivação da vontade cósmica. A justiça eterna, logo,

[...] furta-se ao olhar turvado pelo conhecimento que segue o princípio de razão, o principium individuationis. Esse olhar perde completamente de vista aquela justiça [...]. Vê o homem mau, após perfídias e crueldades de todo tipo, viver em alegria e deixar o mundo sem ser incomodado. Vê o oprimido arrastar-se numa vida cheia de sofrimento, até o seu fim, sem que apareça um vingador ou retaliador. Mas só conceberá e apreenderá a justiça eterna quem se elevar por sobre o conhecimento que segue o fio condutor do princípio de razão, atado às coisas particulares; assim o fazendo, conhece as Ideias, vê através do principium individuationis e percebe que as formas do fenômeno não concernem à coisa-em-si [...]. Verá que a diferença entre quem inflige o sofrimento e quem tem de suportá-lo é apenas fenômeno e não atinge a coisa-em-si, isto é, a Vontade, que vive em ambos [...]. O atormentador e o atormentado são unos. (MVR/WWV I 63, p. 418-419).

Schopenhauer sustenta explicitamente que o significado ético da ação e da consciência moral nada mais é que o conhecimento sentido do significado da justiça eterna (cf. MVR/WWV I 64, p. 422). ${ }^{15}$ Esse conceito está intimamente vinculado, portanto, à ideia de uma ordenaçáo moral do mundo, de sorte que funciona como pressuposto tanto de sua doutrina da virtude quanto de sua soteriologia. No que diz respeito ao sentido "estrito" de sua ética, i.e., à sua doutrina da virtude, parece ter sido suficientemente discutida a vinculação entre a fundamentação da moral no conceito de compaixão e a ideia, por definição contida no conceito de justiça eterna, de que todos os fenômenos se equivalem, do ponto de vista da coisa em si. A questão ainda em aberto, e que fornecerá subsídios para a demarcação clara do sentido de uma ordenação

\footnotetext{
${ }^{15} \mathrm{O}$ filósofo apresenta duas características da natureza humana que comprovam que o homem está consciente, embora de modo não claro, da "essência íntima da justiça eterna e da unidade e identidade da Vontade em todos os seus fenômenos, na qual se assenta essa justiça." A primeira pode ser percebida nas situaçóes em que tanto o espectador quanto a parte injuriada são tomados pelo desejo de vingança, diante de uma situação de injustiça. Nessa ocasião, a consciência da justiça eterna é falseada, quando se exige do fenômeno aquilo que concerne apenas à coisa em si. A segunda característica se mostra na situações nas quais um homem se indigna a tal ponto, diante de uma iniquidade sofrida por outrem, que, mesmo apenas como testemunha, se coloca deliberadamente a tarefa de exercer a vingança em nome do outro (cf. MVR/WWV I 64, p. 423-424).
} 
moral de mundo, na filosofia de Schopenhauer, é a da relação entre o sentido "amplo" de sua ética, i.e., de sua soteriologia, e a noção de justiça eterna. ${ }^{16}$

A soteriologia schopenhaueriana só se torna possível, conforme destacado anteriormente, quando se atinge uma determinada forma de conhecimento, por meio do qual a vontade é suprimida. Dado que violência alguma pode quebrar a vontade cósmica, mas apenas "destruir seu fenômeno, neste lugar, neste tempo", o único caminho possível para a salvação, indica o filósofo, é "que a Vontade apareça livremente, a fim de, neste fenômeno, CONHECER a sua essência." (MVR/WWV I 69, p. 474). Apenas pela ascese, única possibilidade de manifestação da liberdade da vontade, no plano empírico, é que se pode alcançar a redenção (Erlösung) de nosso estado originário, "essencialmente sem salvação":

Nós mesmos, em essência, pertencemos ao que é mau e somos tão firmemente atados a ele que nossas obras, segundo lei e prescriçóes, isto é, conforme motivos, jamais podem satisfazer suficientemente à justiça nem nos redimir, mas a redenção só pode ser ganha por meio da fé, isto é, por uma mudança no modo de conhecimento. (MVR/WWV I 70, p. 482).

A única possibilidade de redenção da existência se dá, por conseguinte, por meio do conhecimento da justiça eterna, que reside na essência do mundo:

Em cada coisa a Vontade aparece exatamente como ela se determina a si mesma e em si, exteriormente ao tempo. O mundo é táo somente o espelho desse querer; e toda infinitude, todo sofrimento, todo tormento no mundo contidos pertencem à expressão daquilo que a vontade quer e são o que sáo em virtude da Vontade querer dessa forma. Em conformidade com isso, todo ser assume com extrema justiça a existência em geral, logo, a existência da sua espécie e a da própria individualidade [...]; mas, em tudo o que acontece e pode acontecer a cada um, a justiça sempre lhe é feita, pois sua é a Vontade. Tal qual a Vontade é, é o mundo. A responsabilidade pela existência e pela índole deste mundo só este mesmo pode assumir, ninguém mais; pois como outrem poderia ter assumido essa responsabilidade? - Caso se queira saber, em termos morais, o que valem os homens no todo e em geral, considere-se seu destino no todo e em geral: trata-se de carência, miséria, penúria, tormento e morte. A justiça eterna prevalece. Se os homens, tomados como um todo, não fossem tão indignos, entấo seu destino, também tomado como um todo, não seria táo triste. Nesse sentido podemos dizer: o mundo mesmo é o tribunal do

16 Toma-se por referência, nesse contexto, a distinção estabelecida por David Cartwright entre uma ética em sentido "estrito" e uma ética em sentido "amplo", no pensamento de Schopenhauer (cf. CARTWRIGHT 2005, p. 252ss.). 
mundo. Pudesse alguém colocar toda a penúria do mundo em UM prato da balança, e toda culpa no outro, o fiel permaneceria no meio. (MVR/ WWV I 63, p. 415-416).

Em que medida a justiça eterna está, portanto, relacionada à soteriologia schopenhaueriana? Pode-se concluir, do que foi até aqui exposto, que o conhecimento que torna possível tanto a doutrina da virtude quanto a soteriologia do filósofo é o conhecimento da justiça eterna, com a diferença de que, no primeiro caso, ele se manifesta na compaixão - quer dizer, enquanto uma virtude, ou enquanto a virtude primordial que fundamenta todas as demais; e, portanto, no plano da motivação -, ao passo que, no segundo, ele se manifesta na ascese - ou seja, enquanto doutrina da liberdade e da salvação.

A ética "descritiva" do filósofo, discutida anteriormente, se dá tanto em função de seu significado metafísico, cujo fundamento reside na noção de compaixão e se desenvolve para uma doutrina da liberdade e da salvação, quanto da ordenaçấo moral de mundo, que acaba de ser apresentada em sua relação de íntima pertença com a concepção de justiça eterna. A análise de aspectos centrais da teoria do conhecimento de Schopenhauer, que ocupa lugar preponderante em sua metafísica "imanente", nos atestou como o autor, por meio da concepção de conhecimento intuitivo, constrói não apenas a sua crítica a toda forma de conhecimento abstrato, mas também a sua forte oposição a qualquer forma de transcendência - daí também o seu "ateísmo". E quais são as implicaçóes de tal concepção de metafísica para a análise do fenômeno moral? Por um lado, Schopenhauer estabelece a significação metafísica da ética, sobretudo em suas análises da compaixão, porém, ainda em como esta só é possível por meio de um conhecimento intuitivo. Mas, por outro - e esse é o problema principal do presente texto -, o filósofo concebe a própria metafísica como ética, ao tratar de uma ordenação moral de mundo, em cujas análises o conceito de justiça eterna ocupa função seminal. Tudo indica, nesse ponto, que o significado metafísico da existência seja, em última instância, um significado ético - com o que se faz necessário determinar, de modo mais claro, a relação entre metafísica e ética no sistema do autor. Para tanto, deve-se tentar compreender em que medida tal relação entre a significação metafísica da ética e a ordenação moral de mundo - ou, formulado de outro modo, entre a significação metafísica da ética e a significação ética da metafísica - interfere na interpretação schopenhaueriana do sentido e do valor da existência. 


\section{A ORDENAÇÁO MORAL DE MUNDO É UMA FORMA DE JUSTIFICAÇÁO DA EXISTÊNCIA?}

A pergunta para a qual se deve procurar oferecer uma resposta, como conclusão da discussão até aqui levada a cabo, é a seguinte: a ordenação moral de mundo é uma possível resposta ao problema colocado pelo "pessimismo" da filosofia de Schopenhauer, i.e., ao problema do "sentido da vida"? 17 Estaria a existência, por meio de tal ordenação, "justificada”? ${ }^{18}$ Qual é, em última instância, a relação entre ordenação moral de mundo e justificação da existência?

Há, a meu ver, ao menos duas respostas possíveis a essas perguntas.

1. A primeira é oferecida por Matthias Kossler, um dos mais notáveis intérpretes do pensamento schopenhaueriano, na atualidade, o qual vem defendendo a tese de que o "significado moral de mundo" da filosofia schopenhaueriana está intimamente vinculado à sua concepção de metafísica, antes mesmo de esta ser formulada em termos de uma "metafísica da vontade". De acordo com Kossler, a introdução da ideia de "caráter inteligível”, já na tese de doutoramento Sobre a quadrúplice raiz do princípio de razão suficiente

\footnotetext{
${ }^{17}$ Já as primeiras interpretaçóes do pessimismo em Schopenhauer indicavam como o tema estava intimamente relacionado à pergunta pelo sentido da vida, principalmente em funçáo de alguns de seus seguidores e críticos, tais como Eduard von Hartmann e Eugen Dühring, os quais questionam se seria possível atribuir um sentido, um valor, ao "todo" da existência. De acordo com Volker Gerhardt (1995, col. 817), o pessimismo schopenhaueriano é o responsável pela popularização do tema do "sentido da vida” na filosofia. Cf. esp. Hauff (1904), Stäglich (1951/2), Gerhardt (1989), Pauen (1997), Dahlkvist (2007) e De Paula (2013). Espero poder tratar em outro artigo do tema do sentido da vida na filosofia alemã do século XIX, indicando alguns de seus desdobramentos mais relevantes para o pensamento contemporâneo.

${ }^{18}$ Atribuir um sentido à existência é o mesmo que perguntar pela sua justificaçáo (Rechtfertigung). Este é precisamente o significado, estabelecido na tradição filosófica, a partir da filosofia de Schopenhauer, do termo pessimismo: "o pessimismo é a noção de que a vida não pode ser justificada, o que significa o mesmo que a não-existência é preferível à existência.” (DAHLKVIST 2007, p. 14). Dentre os sentidos que o termo comporta ao longo da história da filosofia, um parece ser bastante relevante no contexto das discussóes sobre o pessimismo - sentido este que, especialmente no caso de Schopenhauer, nos remete ao problema da justiça eterna. Trata-se da leitura que o apóstolo Paulo (e, mais tarde, Lutero) faz da narrativa segundo a qual Deus absolve o homem de seus pecados, por meio da entrega de seu filho aos plenos poderes do Espírito Santo, de tal modo que o homem se reconcilia (versöhnt) com Deus (cf. PETERS 1989, col. 251-256; 259). Paulo associa o conceito de justificação ao conceito de fé, no sentido de que a "justiça de Deus" se revela ao homem apenas pela fé. À justiça divina se contrapóe a injustiça dos homens, que são os culpados pela sua existência. Justificar pela fé significa aqui se salvar, se redimir, se reconciliar com Deus, com a justiça divina (cf. Epístola aos romanos 1, $16-17 ; 3,27-31 ; 3,4-6 ; 3,9-18 ; 5,1-11 ; 5,18-21)$. Tal tema, típico da tradiçấo teológico-cristâ, nos fornece claros indícios, por um lado, dos interlocutores de Schopenhauer, ao tratar da justiça eterna, bem como, por outro, daquilo que o autor pretende se afastar e se opor, ao conceber uma metafísica imanente e "ateísta".
} 
(Ueber die vierfache Wurzel des Satzes vom zureichenden Grunde), de 1813, demarca claramente o propósito de Schopenhauer de inserir a ação humana no âmbito princípio de razão - com o que o autor cairia necessariamente no campo da metafísica: trata-se aqui do "sujeito do querer como um todo", do sujeito atemporal, e não do sujeito no âmbito do empírico. Nesse texto, afirma o intérprete,

[...] a metafísica será, através da doutrina do caráter, não somente completamente preparada, mas já introduzida na forma especial de uma "metafísica imanente" [...]. Essa metafísica não reivindica dispor de conhecimentos que ultrapassam a experiência; mas ela parte de consideraçôes retornam indiretamente à empiria e que devem ser pressupostos nesta, para que a "Experiência como um todo" possa se tornar compreensível. Na tese, isto significa assumir um idêntico sujeito do querer em suas ações. Esse [...] caráter inteligível acrescentado pelo pensamento [...] coloca as ações individuais da vontade em conexão, a qual revela as respectivas açôes como pertencentes e imputáveis a este. Desse modo, só serão julgadas moralmente ocorrências relacionadas às açóes de uma pessoa, se determinadas pela maneira da pessoa reagir a certas situaçóes e pelas quais a pessoa é moralmente responsável. Assim, o pressuposto metafísico não resulta imperativamente do fato empírico [...], mas necessariamente da condição de que as açóes humanas têm um significado moral. Se quanto mais eu considero o humano como um ser moral, lhe imputo suas açóes e o faço responsável por elas, mais eu preciso do pressuposto de um caráter inteligível [...]. Com a metafísica da Vontade amadurecida, esse modelo humano será transferido para o mundo. (KOSSLER, 2014, p. 19-20).

Desse modo, ao atribuir à doutrina do caráter inteligível uma anterioridade em relação à concepção de metafísica imanente, Kossler se afasta de autores como Rudolf Malter, para quem "a filosofia de Schopenhauer é, como um todo, ética, por causa dos pensamentos de redenção [...] que a determinam" (KOSSLER, 2014, p. 12), no intuito de afastar a pergunta pela ordenação moral de mundo da pergunta pela justificação da existência. Graças à questão do significado moral do mundo, que representa o "ponto central" da filosofia schopenhaueriana, "o mundo apresenta significado e sentido, pois as ocorrências e as coisas conectam-se por meio de uma Vontade que se exterioriza através delas mesmas e são com isso colocadas em uma correlação permanente." (KOSSLER, 2014, p. 26). Que o mundo apresente um "significado moral" não implica, entretanto, que ele tenha um "valor moral": o primeiro é, na concepção de Kossler, o pressuposto para o segundo, uma vez que uma reposta ao problema 
da justificação da existência deve ser encontrada na "liberdade do ser humano, na vontade de viver" e não na metafísica. Enfatiza Kossler (2014, p. 28):

\begin{abstract}
$\mathrm{O}$ pensamento sobre a redençáo, o qual diz respeito à negaçáo da vontade de viver, năo pertence, portanto, à metafísica, pois ele não atinge $o$ significado moral do mundo, mas somente o seu julgamento (Bewertung). A metafísica de Schopenhauer é originariamente ética não por causa deste julgamento, que fundamenta o 'pessimismo' de sua doutrina, mas porque ela está inseparavelmente ligada à significatividade (Bedeutsamkeit) moral do mundo.
\end{abstract}

A tese desenvolvida por Kossler tem o inequívoco mérito de estabelecer, de maneira clara, a diferença entre significação moral de mundo e a pergunta pela justificação da existência, na medida em que situa o problema da caracterização da metafísica como "moral", por Schopenhauer, no âmbito de suas reflexōes mais fundamentais sobre o caráter inteligível (o qual, conforme dito, inclusive antecedem a formulação de sua metafísica da vontade). O intérprete, contudo, parece minimizar o fato de que a pergunta pela justificação da existência perpassa toda a obra do filósofo alemão, de sorte que ordenação moral de mundo e justificação da existência passam a ser tratados quase sempre no mesmo contexto - cabendo, portanto, a nós, leitores e intérpretes, indicar em que medida elas se relacionam, ao longo da obra de Schopenhauer.

2. A segunda resposta não vai exatamente na contramão daquilo que é defendido por Kossler, porém, leva em conta o fato de que o próprio Schopenhauer náo determina de modo claro, no decorrer de sua obra, a diferença entre a significação moral da metafísica e a possibilidade de atribuição de sentido à existência, de forma que esses conceitos são tratados em contextos muito próximos, conforme ficou demonstrado nas análises anteriores sobre a "justiça eterna”. O filósofo, na verdade, parece nos indicar um vínculo entre o significado moral da metafísica e a possibilidade de "redenção" da existência, na medida em que a metafísica é moral, porque está amparada no conceito de justiça eterna e a redenção da existência é possível, via ascese, porque, do ponto de vista da "vontade cósmica”, não há qualquer diferença entre quem causa e quem padece sofrimento - e a ascese seria precisamente a forma de conhecimento que possibilita ultrapassar o âmbito das objetivaçóes da vontade cósmica.

O conceito de justiça eterna, entretanto, ainda que utilizado por Schopenhauer para tratar tanto da ordenação moral de mundo quanto da redenção, não alcança o âmbito do julgamento da existência, o qual só é possível 
graças ao caráter eminentemente ético da metafísica, como defende Kossler. A ordenação moral de mundo funciona, assim, como um pressuposto para a possibilidade de atribuição de sentido à existência. Schopenhauer só pode afirmar, ao escrever $O$ mundo como vontade e representação, que a existência é essencialmente sofredora - e que, portanto, melhor seria não existir -, visto que, fundamentalmente, é provido de liberdade - garantida pelo caráter moral da metafísica - para fazer tal julgamento. O significado moral da existência não implica necessariamente, portanto, um determinado juízo sobre o sentido da existência, pois, a despeito de haver uma "justiça eterna", que, do ponto de vista cósmico, faça com que o mundo seja o tribunal do mundo, o vir a ser, a existência, não é com isso provida de sentido, não é justificada. Muito pelo contrário, ela é definida pelo autor como um delito: "como não seria um delito, se, conforme uma lei eterna, a morte vem depois?” (WWV/MVR I 63, p. 419)

Resta ainda uma questão fundamental, decorrente das afirmaçôes anteriores: a possibilidade de redenção da existência via ascese, narrada no exemplo paradigmático do Cristianismo, pela doutrina e morte de Jesus Cristo (cf. WWV/MVR II 48, p. 719-720), não significaria que a existência, i.e., o vir a ser, estaria justificado? A resposta a essa questão é negativa, pois redenção e justificação possuem significados e escopos diversos, na obra de Schopenhauer, na medida em que a redenção é uma tentativa de solução para o problema apresentado pelo julgamento de que a existência não pode ser justificada, mas, no máximo, redimida.

PAULA, W. A. Moral ordination of the world and justification of existence in Schopenhauer's metaphysics. Trans/form/ação, Marília, v. 43, n. 1, p. 255-282, Jan./Mar., 2020.

\footnotetext{
AbSTRACT: Arthur Schopenhauer is known as the thinker of "philosophical pessimism". It means, in general lines, the doctrine that presents a certain worldview, but in its more basic sense, it questions the possibility of giving a meaning to the whole of existence: is there "justification" (Rechtfertigung) for the existence? By answering this question the German philosopher develops his "metaphysics of the will" and, as its unfolding, his theory of "redemption" (Erlösung), or soteriology. However, the "philosopher of pessimism" also asserts in his work that there is a "moral ordinance of world" (moralische Weltordnung) and a "moral meaning of existence" (moralische Bedeutung des Daseyns), which seems to go on the opposite direction of what is claimed by the "pessimism". The present paper analyses the sense of the notions of moral ordinance of world and justification of existence in Schopenhauer's thought, in order to demonstrate how far moral meaning of life and philosophical pessimismo interact in his thought.
} 
KeY-Words: Arthur Schopenhauer. Metaphysics. Philosophical Pessimism. Moral Ordinance of World. Justification of Existence.

\section{REFERÊNCIAS}

CARTWRIGHT, David. E. Historical Dictionary of Schopenhauer's Philosophy. Oxford: Historical Dictionaries of Religions, Philosophies, and Movements, n. 55, 2005.

CONSTÂNCIO, João. Arte e Niilismo. Nietzsche e o Enigma do Mundo. Lisboa, Portugal: Tinta-da-China, 2013.

DAHLKVIST, Tobias. Nietzsche and the Philosophy of Pessimism. A study of Nietzsche's Relation to the Pessimistic Tradition: Schopenhauer, Hartmann, Leopardi. Uppsala: Uppsala Studies in History of Ideas, n. 35, 2007.

DE PAULA, Wander A. Nietzsche e a transfiguração do pessimismo schopenhaueriano: a concepção de filosofia trágica. 2013. 329 f. Tese (Doutorado em Filosofia) - Instituto de Filosofia e Ciências Humanas, Universidade Estadual de Campinas, Campinas, 2013.

GERHARDT, Volker. Pessimismus. In: RITTER, Joachim; GRÜNDER, Karlfried (org.). Historisches Wörterbuch der Philosophie. P-Q. Basel und Darmstadt, 1989. Col. 386-395. v. 7.

GERHARDT, Volker. Sinn des Lebens. In: RITTER, Joachim; GRÜNDER, Karlfried (org.). Historisches Wörterbuch der Philosophie. Se-Sp. Basel und Darmstadt, 1995. Col. 815-824. v. 9.

HALLICH, Oliver. Ethik. In: SCHUBBE, Daniel; KOßLER, Matthias. SchopenhauerHandbuch. Leben-Werk-Wirkung. Stuttgart/Weimar, Alemanha: J. B. Metzler, 2014. p. 73-85.

HAUFF, Walter von. Die Überwindung des schopenhauerschen Pessimismus durch Friedrich Nietzsche. Halle: C. A. Kaemmer \& Co., 1904.

KOSSLER, Matthias. Uma metafísica originariamente ética: metafísica e significado moral na tese de Schopenhauer. In: CARVALHO, Ruy de; COSTA, Gustavo; MOTA, Thiago (org.). Nietzsche-Schopenhauer, metafísica e significação moral do mundo. Fortaleza: EdUECE, 2014. p. 11-28.

PAUEN, M. Pessimismus. Geschichtsphilosophie, Metaphysik und Moderne von Nietzsche bis Spengler. Berlin: Akademir, 1997.

PETERS, A. Rechtfertigung. In: RITTER, Joachim; GRÜNDER, Karlfried (org.). Historisches Wörterbuch der Philosophie. Basel und Darmstadt, 1989. Col. 251ff. v. 8 PFLUG, G. Lebensphilosophie. In: RITTER, Joachim; GRÜNDER, Karlfried (org.). Historisches Wörterbuch der Philosophie. LMn. Basel und Darmstadt, 1989. Col. 135-140. v. 5 . 
SCHOPENHAUER, A. O mundo como vontade e como representação. Tradução de Jair Barboza. São Paulo: UNESP, 2005. t. 1.

SCHOPENHAUER, A. O mundo como vontade e como representação: Suplementos aos quatro livros do primeiro tomo. Tradução de Jair Barboza. São Paulo: UNESP, 2015. t. 2. SCHOPENHAUER, A. Sobre o fundamento da moral. Tradução de Maria Lúcia Cacciola. São Paulo: Martins Fontes, 1995.

SCHNÄDELBACH, H. Philosophy in Germany. Translated by Eric Matthews. London: Cambridge University Press, 1984.

STÄGLICH, H. Zur Geschichte des Begriffs Pessimismus. Schopenhauer-Jahrbuch, n. 34, p. 27-37,1951/1952.

YOUNG, J. Is Schopenhauer an Irracionalist? Schopenhauer-Jahrbuch, n. 69, p. 85-100, 1988. 